\title{
FAKTOR YANG MEMPENGARUHI PRAKTIK MENYUSUI PADA IBU POST SECTIO CAESAREA DI RSI A. YANI SURABAYA
}

\author{
Uke Maharani Dewi \\ Fakultas Keperawatan dan Kebidanan \\ Universitas Nahdlatul Ulama Surabaya J1. Smea 57 Surabaya \\ Email: uke@unusa.ac.id
}

\begin{abstract}
: factors that affect the practice of nursing in the mother post section caesarea. Various programs to support the delivery of ASI has intensified coverage of ASI but still does not meet the expected target. Previous studies showed that breastfeeding initiation was late in babies born with sectio caesarea compared to those with vaginal delivery and prevalence of exclusive breastfeeding practice was low in the former group. The objective of this study was to define factors correlated breast feeding practice initiation on post sectio caesarea mother. 72 post sectio caesarea mothers were observed and interviewed on January 2012 to find the factors correlated with breastfeeding practice. The results showed that although $26.4 \%$ of them had previous experience in breastfeeding, only $6.9 \%$ and $29.2 \%$ of total breastfeeding is started on the first and second post sectio caesarea respectively. Support for breastfeeding practice from health workers was low, and there were significant correlation between the support and rooming conditions with breastfeeding practices $(\mathrm{p}=0.001)$.
\end{abstract}

Abstrak: Faktor yang mempengaruhi praktik menyusui pada ibi post sectio caesarea. Berbagai program untuk mendukung pemberian ASI telah digalakkan namun cakupan pemberian ASI masih belum memenuhi target yang diharapkan. Penelitian terdahulu menyebutkan bahwa ibu melahirkan secara sectio caesarea cenderung lebih lambat melakukan inisiasi menyusu dini dan mempunyai prevalensi lebih rendah dalam praktik ASI ekslusif dibanding Ibu melahirkan pervaginam.Tujuan penelitian ini adalah mengetahui faktor yang mempengaruhi praktik inisiasi ASI pada Ibu post sectio caesarea di RSI. A. Yani Surabaya. Sebanyak 27 ibu yang melahirkan secara sectio caesarea selama bulan Januari 2012 telah menandatangani informed consent, observasi dilakukan sejak ibu masuk rumah sakit sampai akhir hari ke-2 post sectio caesarea. Hasil penelitian menunjukkan 26,4\% di antaranya sudah mempunyai pengalaman sebelumnya dalam memberikan ASI, tetapi hanya 6,9\% dan total 29,2\% yang mulai memberikan ASI pada hari pertama dan kedua pasca sectio caesarea. Dukungan tenaga kesehatan dalam hal membantu proses pemberian ASI dilaporkan masih rendah. Uji korelasi mendapatkan bahwa dukungan tenaga kesehatan dan kondisi rawat gabung adalah faktor yang berhubungan dengan praktik pemberian ASI ( $\mathrm{p}$ value 0,$39 ; \mathrm{p}=0,001 ; \mathrm{p}$ value $=0,47 ; \mathrm{p}=0,001$ ).

Kata kunci: menyusui, sectio caesarea

\section{PENDAHULUAN}

Air susu ibu (ASI) merupakan makanan terbaik dan tidak tergantikan oleh apapun untuk tumbuh kembang bayi, menunjang kesehatan bayi secara optimal, serta mewujudkan ikatan emosional antara ibu dan bayinya.

Target ASI eksklusif Indonesia Sehat 2010 adalah 80\%. Prevalensi sectio caesarea terus meningkat dari tahun ke tahun, terutama di kota besar. Menurut data 
Survei Demografi dan Kesehatan Indonesia tahun 2007, sectio caesarea menyumbang penurunan angka kematian ibu (AKI) sebesar $25 \%$, tetapi hal tersebut perlu diwaspadai karena bayi yang lahir melalui sectio caesarea mempun dibandingkan persalinan pervaginam. Hal ini dapat disebabkan beberapa hal misalnya, kondisi post sectio caesarea membuat ibu merasa nyeri dan menjadi sulit untuk menyusui bayinya, keterlambatan untuk melakukan inisiasi menyusui dini dapat menurunkan sekresi prolaktin.

Tinjauan sistematis yang melibatkan 33 negara mendapatkan hasil bahwa prevalensi menyusui dini lebih rendah pada ibu post sectio caesarea dibandingkan dengan yang melahirkan pervaginam. Data studi terdahulu juga menemukan bahwa, 100\% ibu post sectio caesarea tidak memulai menyusui bayinya pada hari pertama melahirkan. Tanpa membedakan jenis persalinan, pervaginam atau sectio caesarea, secara umum pemberian ASI dipengaruhi beberapa faktor, antara lain dukungan tenaga kesehatan, keadaan ibu (fisik dan psikologis), perubahan sosial budaya, tata laksana di rumah sakit, kesehatan bayi, sikap ibu, lingkungan keluarga, peraturan pemasaran pengganti ASI, dan paritas. Ditengarai bahwa 24 jam setelah ibu melahirkan adalah saat yang sangat penting untuk inisiasi pemberian ASI dan akan menentukan keberhasilan menyusui selanjutnya. Jika ibu tidak mulai memberikan ASI lebih dari dua hari setelah post partum, respons pengeluaran prolaktin akan sangat menurun. Situasi ini terjadi pada persalinan dengan sectio caesarea.

Pemberian ASI oleh ibu yang telah menjalani sectio caesarea sebenarnya dapat langsung dilakukan karena operasi dilakukan dengan anestesi spinal atau epidural sehingga ibu tetap sadar. Posisi menyusui dapat disesuaikan dengan kondisi ibu, misalnya dengan posisi berbaring (lying down), posisi duduk, dan football hold sehingga hal ini sebenarnya tidak menjadi penghalang bagi praktik pemberian ASI. Mengingat semakin banyaknya ibu melahirkan dengan sectio caesarea, pentingnya menyusui dini demi kesuksesan keberlangsungan pemberian ASI kepada bayi, serta pentingnya peran petugas kesehatan dalam mendukung pemberian ASI terutama pada hari-hari pertama melahirkan, maka penelitian ini ingin mempelajari faktor - faktor yang mempengaruhi praktik pemberian ASI pada ibu melahirkan dengan sectio caesarea yaitu, sikap ibu, status paritas, dan karakteristik ibu dengan praktik menyusui.

\section{METODE}

Desain penelitian ini adalah analitik observasional. Populasi penelitian adalah semua ibu melahirkan dengan sectio caesarea yang masuk dalam kriteria inklusi pada periode Januari 2012 di RSI. A. Yani Surabaya yang berjumlah 27 responden. Kriteria inklusi adalah ibu tidak mempunyai penyakit lain (jantung, kanker, preeklampsia/eklampsia, luka herpes pada payudara), ibu dengan bayi yang normal, bayi dapat minum per-oral, bayi yang tidak menerima cairan melalui infus, bayi yang menderita galaktosemia. Jika setelah sectio caesarea ibu memerlukan terapi khusus, kondisi tidak stabil, perdarahan, gangguan kesadaran, kondisi bayinya tidak normal dan atau memerlukan terapi khusus, maka ibu tersebut dikeluarkan sebagai responden. Besar sampel adalah 27 responden.

Variabel independen dalam penelitian ini adalah praktik pemberian ASI, adapun variabel dependennya adalah: Dukungan tenaga kesehatan, Pengetahuan ibu, Sikap ibu, Paritas, Riwayat menyusui. Instrumen yang digunakan dalam penelitian adalah lembar observasi dan kuesioner. Analisis 
data menggunakan uji statistik chi square dan disajikan dalam bentuk tabel dan narasi.

\section{HASIL DAM PEMBAHASAN}

\section{a. Hasil}

Hasil observasi menunjukkan bahwa 12 ibu $(44,4 \%)$ sudah mengeluarkan ASI pada hari pertama post sectio caesarea tetapi hanya $3 \mathrm{ibu}(11,1 \%)$ yang memberikan ASI kepada bayinya pada hari tersebut. Sebanyak 27 ibu melahirkan dengan cara sectio caesarea, 5 orang $(18,5 \%)$ belum berada satu ruang dengan bayinya (rawat gabung) pada hari pertama. Petugas akan memberikan bayi kepada ibunya untuk disusui jika si ibu sudah kentut dan kateter urin serta infus sudah dilepas. Dukungan tenaga kesehatan dalam praktik inisiasi dini ASI dinilai baik oleh sebagian kecil responden $(37 \%)$, cukup $(25,9 \%)$, dan dinilai kurang oleh responden (37\%). Dari $12 \mathrm{ibu}$ yang sudah memproduksi ASI pada hari pertama post sectio caesarea, hanya 3 ibu $(11,1 \%)$ yang memberikan ASI kepada bayi (praktik menyusui), sementara $75 \%$ ibu tidak memberikan ASI yang sudah keluar kepada bayinya. Tidak ada perbedaan usia ibu yang menyusui bayinya pada hari pertama postpartum dengan ibu yang tidak menyusui bayinya. Status paritas dan sikap ibu tentang pentingnya pemberian ASI juga tidak ada hubungannya dengan praktik pemberian ASI hari pertama sectio caesarea.

\section{b. Pembahasan}

1. Pengaruh dukungan tenaga kesehatan terhadap praktik menyusui pada ibu post sectio caesarea di RSI A. Yani Surabaya

Penelitian ini menunjukkan bahwa dukungan tenaga kesehatan dan praktik rawat gabung (ibu dan bayi dalam satu ruangan) mempengaruhi tindakan ibu untuk menyusui bayi secara dini (nilai $\mathrm{p}=0,28 ; \mathrm{p}$ $=0,001$; nilai $\mathrm{p}=0,32 ; \mathrm{p}=0,001)$. Kondisi ibu pasca sectio caesarea sangat memerlukan dukungan dari tenaga kesehatan dengan menunjukkan bayi kepada ibu dan memberikan bayi untuk disusui. Hal ini terbukti sangat membuat kondisi ibu nyaman dan puas. Intervensi "early skin to skin" pasca sectio caesarea terbukti meningkatkan praktik menyusui dan dinyatakan bahwa peranan perawat adalah kunci keberhasilan program intervensi tersebut. Pentingnya dukungan tenaga kesehatan terhadap praktik menyusui juga ditunjukkan oleh Labarere dkk, yang menyatakan bahwa kunjungan tenaga kesehatan bulan kesatu hingga keenam pada ibu melahirkan setelah keluar rumah sakit ada hubungannya dengan prosentasi ibu memberikan ASI ekslusif dan dengan durasi menyusui (Moore, et al, 2007)

2. Pengaruh pengetahuan ibu terhadap praktik menyusui pada ibu post sectio caesarea di RSI A. Yani Surabaya

Tidak ada hubungan antara pengetahuan tentang pentingnya pemberian ASI dengan praktik menyusui dini pada hari pertama postsectio caesarea.

Penelitian di Hongkong menunjukkan bahwa suami sangat berperan pada praktik inisiasi ibu untuk menyusui bayinya sedangkan tingkat pendidikan ibu yang tinggi dan status ibu bekerja berhubungan dengan dihentikannya pemberian ASI oleh ibu yang diganti dengan pemberian susu formula (Nakao, et al, 2007).

3. Pengaruh sikap ibu terhadap praktik menyusui pada ibu post sectio caesarea di RSI A. Yani Surabaya

Tidak ada hubungan antara sikap ibu tentang pentingnya pemberian ASI dengan praktik menyusui dini pada hari pertama postsectio caesarea.

Notoatmodjo, 2011, menyatakan bahwa sikap terhadap nilai-nilai kesehatan tidak selalu terwujud dalam suatu tindakan nyata. Ibu yang telah menjalani operasi lebih memilih untuk pasif dan beristirahat 
daripada segera memberikan ASI pada bayinya walaupun ibu tahu bahwa ASI merupakan makanan terbaik bagi bayi. Selain itu, tenaga kesehatan setempat juga tidak menganjurkan dan mendukung ibu untuk sesegera mungkin memberikan ASI, yang mengakibatkan penundaan inisiasi menyusui bayi secara dini. Keterlambatan tersebut dapat menu- runkan sekresi prolaktin, zat esensial untuk memproduksi dan menjaga kestabilan produksi ASI yang selanjutnya akan memengaruhi kecukupan ASI ekslusif bagi bayi.

4. Pengaruh paritas terhadap praktik menyusui pada ibu post sectio caesarea di RSI A. Yani Surabaya

Tidak ada hubungan antara paritas dengan praktik menyusui dini pada hari pertama postsectio caesarea.

Penelitian ini sejalan dengan penelitian yang dilakukan oleh Zul Sathri (2010) yang menyatakan bahwa jumlah anak tidak berpengaruh terhadap lamanya menyusui.

Hasil penelitian ini tidak sejalan dengan Andrianto (2009), yang menyatakan bahwa semakin tinggi tingkat paritas ibu maka berpengaruh positif terhadap pemberian ASI eksklusif.

Secara teoritis paritas diperkirakan ada kaitannya dengan arah pencarian informasi tentang pengetahuan ibu nifas/menyusui dalam memberikan ASI eksklusif (Pamella, 2010).

5. Pengaruh riwayat menyusui pada kehamilan sebelumnya terhadap praktik menyusui pada ibu post sectio caesarea di RSI A. Yani Surabaya

Tidak ada hubungan antara riwayat menyusui dengan praktik menyusui dini pada hari pertama postsectio caesarea. Hal ini sejalan dengan penelitian Mardiyaningsih, 2010 yang menyatakan bahwa pengalaman menyusui sebelumnya tidak berpengaruh terhadap pemberian ASI.

Penelitian ini tidak sejalan dengan Nakao, 2007 bahwa riwayat menyusui sebelumnya berpengaruh terhadap pemberian ASI berikutnya.

Secara teoritis kegagalan ataupun keberhasilan dalam pemberian ASI pada persalinan sebelumnya merupakan pengalaman yang akan dijadikan pedoman bagi ibu untuk proses pemberian ASI pada persalinan berikutnya (Otsuki, 2009).

\section{SIMPULAN}

Praktik pemberian ASI oleh ibu post sectio caesarea kepada bayinya dipengaruhi oleh beberapa faktor yaitu dukungan tenaga kesehatan dan praktik rawat gabung.

\section{SARAN}

Bagi rumah sakit perlu meningkatkan kebijakan yang mendukung inisiasi menyusui dini khususnya bagi ibu melahirkan dengan sectio caesarea dan tenaga kesehatan perlu secara aktif memberikan dukungan pada ibu post sectio caesarea untuk segera melakukan inisiasi pemberian ASI bagi bayinya. Sedangkan bagi masyarakat yakni perlu adanya kesadaran yang tinggi terhadap pentingnya ASI untuk bayi.

\section{DAFTAR PUSTAKA}

Mardiyaningsih E., 2010. 'Efektivitas kombinasi teknik marmet dan pijat oksitosin terhadap produksi ASI ibu post seksio sesarea di rumah sakit wilayah jawa tengah'. Jurnal FIK UI

Moore E.R., Anderson G.C., Bergman N., 2007. 'Early skin-to-skin contact for mothers and their healthy newborn infants (Review)'. Cochrane review: 4

Nakao Y., Moji K., Honda S., 2007. 'Initiation of breastfeeding within 
120 minutes after birth is associated with breastfeeding at four months among Japanese women: a self administered quotionnaire survey'. International breastfeeding journal: 3(1)

Sathri Z., 2010. 'Efektivitas paket 'bunda ceria' terhadap rasa nyeri dan pembengkakan payudara serta produksi ASI pada ibu post partum jakarta'. Jurnal FIK UI

Andrianto., 2009. 'Faktor-faktor yang berhubungan dengan produksi air susu ibu pada ibu pasca seksio sesarea di wilayah kota dan kabupaten tasikmalaya'. Jurnal FIK UI

Otsuki Y., Yamaji K., Fujita M., 2009. 'Serial plasma oxytocin levels during pregnancy and labor'. Journal of Department of obstetrics and gynecology Osaka university medical school: 62(1): 15-18

Pamella J., 2010. 'Impact of early initiation of exclusive breastfeeding on newborn deaths'. Technical Brief Issue; 1(1) 